\title{
Prevalence of benign proliferative breast lumps among females with benign breast diseases in Sohag governorate
}

\author{
Hosam F AbdElhameed, MD; Samir A AbdElmeguid, MD; \\ Mohamed M ALI, MD; Ahmed E Ahmed, MD
}

\author{
Surgery Department, Sohag University Hospital, Egypt.
}

Background: Benign breast disease is an important risk factor for a later breast cancer, which can develop in either breast. It includes a spectrum of histologic entities, usually subdivided into non-proliferative lesions, proliferative lesions without atypia, and atypical hyperplasia, with an increased risk of breast cancer associated with proliferative or atypical lesions.

Aim: To estimate the prevalence of benign proliferative breast lumps that carry a risk of developing breast cancer in Sohag governorate.

Patients and methods: This prospective study included 416 female patients presented to Breast Clinic with clinically palpable benign breast lump(s) at Sohag University Hospital; only 390 of them were enrolled in the study. All patients were subjected to thorough clinical examination, sono-mammography and fine needle aspiration cytology. Those who were pregnant or proved to be malignant were excluded. Data including use of contraceptives, Parity, menarche, menopausal status, family history of breast cancer were collected prospectively using a pre-test questionnaire in a face to face interview. All biopsies taken form the excised lumps were examined by three pathologists with experience in breast diseases.

Results: Of 416 females with clinically benign breast lump(s), only 390 were recruited in the study. The prevalence of BPBD was 78/390 (20\%)while non BPBD was 312/390 (80\%). $B P B D$ with atypia was 24/390 (6.1\%), while BPBD without atypia was 54/390 (13.8\%).The commonest breast lesions were fibroadenoma, fibrocystic disease and duct ectasia (54.1\%), (25.6\%) and (5.6\%) respectively.

Conclusion: Benign proliferative breast lumps are common among premenopausal women in Sohaggovernorateand a significant proportion of BPBD had atypical proliferation.

Key words: Breast, benign proliferative disease, atypia, risk factor, aetiology.

\section{Introduction:}

Benign breast disease (BBD) account for about $90 \%$ of whole breast diseases. Because of the increased awareness of breast cancer, benign breast lumps have assumed increasing attention nowadays. ${ }^{1-3}$ Benign breast lesions carry a risk factor for development of either unilateral or contralateral breast cancer. ${ }^{4}$ Histologic entities of benign breast lesions areusually subdivided into non-proliferative breast lesions, proliferative breast lesions without atypical hyperplasia, and proliferative breast lesions with atypical hyperplasia. ${ }^{5-7}$ It has been postulated that inflammatory breast disease and non proliferative breast disease do not increase the risk of cancer. Proliferative breast disease without atypia and with atypia confers mild and moderate risk respectively, whereas carcinoma in situ is associated with substantial risk, ${ }^{8}$ so it is important to pick up the benign lesions having risk of breast cancer development and know its incidence. The aim of our study is to determine the prevalence of benign proliferative breast diseases at risk of developing breast cancer.

\section{Patients and methods:}

This prospective study was conducted at general surgery department, Sohag University Hospital From February 2009 to June 2013; 
it included 416 female patients presented to Breast Clinic with clinically palpable benign breast lump(s).

All patients were subjected to thorough clinical examination, sono-mammography and fine needle aspiration cytology. Those who were pregnant or with clinical and/ or radiological sings of malignancy were excluded. Fine needle aspiration cytology (FNAC) was done as an out patients procedure using Fine-gauge number 23 single-use disposable needles in combination with regular 10 cc single-use airtight disposable plastic syringe. Two to three dry clean slides were used for preparing the smears. All slides were labelled with a glass pencil and airdried then were fixed with $95 \%$ alcohol and stained with eosin and haematoxylin stain. Those who had cytological report negative for malignancy were included in the study. Data including use of contraceptives, Parity, menarche, menopausal status, family history of breast cancer were collected prospectively using a pre-test questionnaire in a face to face interview. A written informed consent was obtained from all patients. The study design was approved by the local research ethics committee. All biopsies taken form the excised lumps were examined by three pathologists with experience in breast diseases each one was initially blinded from findings of the others. In case of discrepancy in reporting, the final decision was by consensus. Gathered data were processed using SPSS version 15 (SPSS Inc., Chicago, IL, USA). Quantitative data were expressed as mean \pm SD while qualitative data were expressed as numbers and percentages (\%). Student $t$ test was used to test significance of difference for quantitative variables while Chi square was used to test significance of difference for qualitative variables. A probability values (p-value) $\leq 0.05$ was considered statistically significant.

\section{Results:}

This prospective study was carried out in the period from February 2009 to June 2013 at department of general surgery, Sohag University hospital, Egypt. It included 416 patients attended breast clinic with clinical features of benign breast lumps, only 390 of them were enrolled in the study. All patients were females; their ages ranged from (12-67 years) with average 27.6 years. The average diameters of the masses were $2.9 \mathrm{~cm}$ (range: 1.0-7.0 cm). The patients, characteristics are shown in Table (1). Benign proliferative breast lesions (BPBL) were found in (20\%) 78/390, while (80\%) 312/390 were non proliferative. Among the BPBL there were 50 patients who did not use hormonal contraception while 28 had been using contraception. The prevalence of BPBL was 7.1 and $12.8 \%$ among hormonal contraceptive users and non-hormonal contraceptive users respectively. 35.8\% (24/78) patients with BPBL had atypia while (69.2\%) 54/78 patients with BPBL were without atypia. The prevalence of BPBL with atypia was $6.1 \%(24 / 390)$ and prevalence of BPBL without atypia was 13.8\% (54/390).

As regard the histological diagnosis of the breast lesions, (54.1\%) 211/390 patients had fibroadenoma; this was followed by Fibrocystic disease in (25.6\%) 100/390 patients. Duct ectasia, the third commonest diagnosis was found in (5.6\%) 22/390 patients. Chronic abscess, lactating adenoma and fat necrosis were found in (4.6\%) 18 , (3.5\%) 14, and (2\%) 8 patients respectively and 17 patients $(4.3 \%)$ had other diagnoses as shown in Table (2). The proliferative nature of all lesions was limited to the fibrocystic disease and fibroadenoma, 35/78 (44.8\%) and 24/78 (30.7\%) respectively.

\section{Discussion:}

Benign breast disease is a well-established risk factor for a later breast cancer, which can develop in either breast. ${ }^{4}$ It encompasses a spectrum of histologic entities, usually subdivided into non proliferative lesions, proliferative lesions without atypical, and atypical hyperplasia, with an increased risk of breast cancer associated with proliferative or atypical lesions. ${ }^{9-11}$ Studies of benign breast disease can clarify whether there is a continuum of breast alterations that culminates in breast cancer. However, it remains unclear which of the benign entities are actual 
Table 1: Participants' characteristics with BPBD and non BPBD.

\begin{tabular}{|c|c|c|c|c|c|c|}
\hline Variable & Parameters & $\begin{array}{c}\text { All } \\
\text { women } \\
(\mathrm{N}=390)\end{array}$ & $\begin{array}{c}\text { Non } \\
\text { BPBD } \\
(\mathrm{N}=312)\end{array}$ & $\begin{array}{l}\text { BPBD } \\
(N=78)\end{array}$ & $\begin{array}{c}\text { Atypical } \\
\text { Hyperplasia } \\
(\mathrm{N}=\mathbf{2 4})\end{array}$ & P-value \\
\hline Percentage of total & & $100 \%$ & $80 \%$ & $20 \%$ & $6.1 \%$ & \\
\hline Age & $\begin{array}{l}10-20 \\
21-30 \\
31-40 \\
40+\end{array}$ & $\begin{array}{l}76 \\
140 \\
111 \\
63\end{array}$ & $\begin{array}{l}48(15.4) \\
128(41.0) \\
98(31.4) \\
38(12.1)\end{array}$ & $\begin{array}{l}28(35.9) \\
12(15.4) \\
14(17.9) \\
24(30.8)\end{array}$ & \begin{tabular}{|l}
$1(4.1)$ \\
$6(25)$ \\
$8(33.3)$ \\
$9(37.5)$
\end{tabular} & 0.001 \\
\hline Menarche & $\begin{array}{l}\leq 13 \text { years } \\
>13 \text { years }\end{array}$ & $\begin{array}{l}372 \\
18\end{array}$ & $\begin{array}{l}309(99) \\
3(1)\end{array}$ & $\begin{array}{l}78(100) \\
0.0\end{array}$ & \begin{tabular}{|l}
$24(100)$ \\
0.0 \\
\end{tabular} & 0.00 \\
\hline Menopause & $\begin{array}{l}\text { yes } \\
\text { No }\end{array}$ & $\begin{array}{l}42 \\
348\end{array}$ & $\begin{array}{l}24(7.7) \\
288(92.3)\end{array}$ & $\begin{array}{l}16(20.5) \\
62(79.5)\end{array}$ & $\begin{array}{l}4(16.6) \\
20(83.4)\end{array}$ & 0.00 \\
\hline Parity & $\begin{array}{l}\text { Null } \\
\operatorname{Low}(1-2) \\
\operatorname{High}(\geq 3)\end{array}$ & $\begin{array}{l}144 \\
126 \\
120\end{array}$ & $\begin{array}{l}96(30.7) \\
107(34.4) \\
109(34.9)\end{array}$ & $\begin{array}{l}48(61.5) \\
19(24.4) \\
11(14.1)\end{array}$ & $\begin{array}{l}13(54.2) \\
7(29.2) \\
4(16.6)\end{array}$ & 0.0002 \\
\hline $\begin{array}{l}\text { Family history of } \\
\text { breast cancer }\end{array}$ & $\begin{array}{l}\text { Yes } \\
\text { No }\end{array}$ & $\begin{array}{l}64 \\
326\end{array}$ & $\begin{array}{l}10(3.2) \\
302(96.8)\end{array}$ & $\begin{array}{l}54(69.2) \\
24(30.8)\end{array}$ & $\begin{array}{l}16(66.6) \\
8(33.3)\end{array}$ & 0.00 \\
\hline Contraceptive use & $\begin{array}{l}\text { Yes } \\
\text { No }\end{array}$ & $\begin{array}{l}130 \\
260\end{array}$ & $\begin{array}{l}102(32.7) \\
210(67.3)\end{array}$ & $\begin{array}{l}28(35.9) \\
50(64.1)\end{array}$ & $\begin{array}{l}7(29.2) \\
17(70.8)\end{array}$ & 0.0007 \\
\hline
\end{tabular}

(P-value $\leq 0.05)=$ significant

Table 2: Frequency of histological types of breast lesions.

\begin{tabular}{|l|l|l|}
\hline Histological diagnosis & Frequency & Percentage \\
\hline fibroadenoma & 211 & $54.1 \%$ \\
\hline Fibrocystic disease & 100 & $25.6 \%$ \\
\hline Duct ectasia & 22 & $5.6 \%$ \\
\hline Chronic abscess & 18 & $4.6 \%$ \\
\hline Lactating adenoma & 14 & $3.5 \%$ \\
\hline Fat necrosis & 8 & $2.0 \%$ \\
\hline Others & 17 & $4.3 \%$ \\
\hline Total & 390 & $100 \%$ \\
\hline
\end{tabular}

precursors and which reflect a background of increased risk involving all breast tissue in a woman. ${ }^{12}$ Retrospective and prospective studies have shown a relative risk of breast cancer of 1.5 to 1.6 for women with benign breast disease as compared with women in the general population. The histologic appearance of the benign lesion is strongly associated with the risk of breast cancer; with non-proliferative changes the relative risk was 1.27 as compared with a relative risk of 1.88 for proliferative changes but no atypia and of 4.2 for atypical hyperplasia.9,13-18 Among women with BBD, a family history of breast cancer (BC) further increases BC risk and women with a family history of $\mathrm{BC}$ are more likely to be diagnosed with BBD, especially at younger ages. ${ }^{12}$ Important questions remain, however, about the degree of risk associated with the common non-proliferative benign entities and the extent to which family history influences the risk of breast cancer in women with proliferative or atypical lesions. Dupont and Page found that women with nonproliferative disease did not have an increased risk of a later breast cancer. ${ }^{9}$ By contrast, a 
companion study to the National Surgical Adjuvant Breast and Bowel Project (NSABP) found a relative risk of 1.6 for women who received a diagnosis of a "lower category" of benign breast. ${ }^{13}$ In our governorate where a large proportion of women with breast cancer are pre-menopausal, it was important to examine and characterize the nature of benign breast lesions encountered in routine clinical practice in our locality. We set out to establish the prevalence of benign proliferate breast lesions with atypia and without atypia. We found that benign breast lesions are a common presentation; $93.7 \%$ as the case elsewhere. In our study $20 \%$ (78/390) of all benign breast lumps were proliferative in nature. Atypia which is considered to carry two to four folds risk for developing breast cancer $(19,20)$ was present in $6 \%(24 / 390)$ of the benign proliferative lumps. Also we found that $83 \%(20 / 24)$ of the women with atypia were premenopausal. This came in accordance with a study by Schnitt et al, 1993, which found the prevalence of BPBD in Japan was as high as $18 \%$ among women younger than 40 years. ${ }^{21}$ A similar finding was documented in North America. ${ }^{22}$ In our series Fibroadenoma was the most frequently diagnosed lesion $54.1 \%$, followed by fibrocystic change $25.6 \%$. Duct ectasia was the third most commonly diagnosed lesion. Almost all of the benign proliferative lesions were found in the fibrocystic change and fibroadenoma catergories. This result came in accordance with result of Chengqu an et al, Shrestha et al and Okota et al.23-25 As regard family history we found that there is a significant association between the positive history of breast cancer and BPBD. In literature the association between family history of breast cancer and risk of BPED is mixed, with some studies finding a positive association $^{26-27}$ and others ${ }^{28-33}$ observing no association. In relation to parity; we found that there is an inverse association between the parity and the risk of BPBD and there are only three studies ${ }^{27,29,32}$ that support this result, while the remaining studies observed no association. ${ }^{28-30,33-36}$

Several studies have also examined the etiological role of exogenous hormone use. $^{29,33,37-41,42}$ Four studies, two cohort ${ }^{33,42}$ and two case-control, ${ }^{29,37}$ have presented results for the association between oral contraceptive (OC) use and risk of BPBD, with two showing that risk of BPBD was reduced in association with OC use ${ }^{29,42}$ and the others ${ }^{37,33}$ showing no association. Several other studies (all case-control) havereported on the association between OC use and risk of BBD by degree of histological atypia. ${ }^{36-40}$ Findings for these studies have varied from those showing reduced risk of all grades of atypia $^{36}$ to those showing no reduction in risk with any grade of atypia. ${ }^{37}$ In this study, no association is found between any measure of oral contraceptive use and risk of BPBD. The association between age at menarche and BPED of the breast has been investigated in nine case-control studies $26-29,31,32,34,35$ and one cohort study, ${ }^{33}$ none of which has shown alterations in risk and this came in agreement with our result.

\section{Conclusion:}

Benign proliferative breast lumps are common among premenopausal women in Sohag governorate and a significant proportion of it had atypical proliferation. Fibroadenoma and fibrocystic disease were the commonest benign breast disease in our locality. An accurate breast cancer risk estimate study for BPBD is recommended.

\section{Reference:}

1- Guray M, Sahin AA: Benign breast diseases: Classification, diagnosis andmanagement. Oncologist 2006, 11(5): 435-449.

2- Armando EG, Doherty GM, Lawrence WW: Benign breast disorders. In: Current surgical diagnosis and treatment. International Edition. $2^{\text {nd }}$ edition. 2006; 297-300.

3- Vaidyanathan L, Barnard K, Elnicki DM: Benign breast disease: When to treat, when to reassure, when to refer. Cleve Clin J Med 2002, 69(5): 425-432.

4- Connolly JL, Schnitt SJ: Benign breast disease: Resolved and unresolved issues. Cancer 1993; 71: 1187-1189.

5- Guray M, Sahin AA: Benign breast diseases: Classification, diagnosis and management. Oncologist 2006, 11(5): 435-449. 
6- Armando EG, Doherty GM, Lawrence WW: Benign breast disorders: In current surgical diagnosis and treatment. International Edition. $2^{\text {nd }}$ edition. 2006; 297-300.

7- Vaidyanathan L, Barnard K, Elnicki DM: Benign breast disease: When to treat, when to reassure, when to refer. Cleve Clin J Med 2002, 69(5): 425-432.

8- Kumar Abbas Fausto: Robbinsand Cotran Pathologic basis of disease. $7^{\text {th }}$ ed. Elsevier, Philadelphia 2004; 1121-1130.

9- Dupont WD, Page DL: Risk factors for breast cancer in women with proliferative breast disease. N Engl J Med 1985; 312: 146-151.

10- Gail MH, Brinton LA, Byar DP, et al: Projecting individualized probabilities of developing breast cancer for white females who are beingexamined annually. J Natl Cancer Inst 1989; 81: 1879-1886.

11- Fitzgibbons PL, Henson DE, Hutter RV: Benign breast changes and the risk for subsequent breast cancer: An update of the 1985 consensus statement, Cancer Committee of the College of American Pathologists. Arch Pathol Lab Med 1998; 122: 1053-1055.

12- Lynn C. Hartmann, Thomas A. Sellers, Marlene H Frost, et al: Benign breast disease and the risk of breast cancer. $N$ Engl $J$ Med 2005; 353(3): 229-237.

13- Wang J, Costantino JP, Tan-Chiu E, Wickerham DL, Paik S, Wolmark N: Lowercategory benign breast disease and the risk of invasive breast cancer. J Natl Cancer Inst 2004; 96: 616-620.

14- Carter CL, Corle DK, Micozzi MS, Schatzkin A, Taylor PR: A prospective study of the development of breast cancer in 16,692 women with benign breast disease. Am J Epidemiol 1988; 128: 467-747.

15- London SJ, Connolly JL, Schnitt SJ, Colditz GA: A prospective study of benign breast disease and the risk of breast cancer. JAMA 1992; 267: 941-944. [Erratum, JAMA 1992; 267: 1780.]

16- Page DL, Schuyler PA, Dupont WD, Jensen RA, Plummer WD Jr, Simpson JF: Atypical lobular hyperplasia as a unilateral predictor of breast cancer risk: A retrospective cohort study. Lancet 2003; 361: 125-129. [Erratum, Lancet 2003; 361:1994.]

17- Kandel R, Li SQ, Ozcelik H, Rohan T: p53 protein accumulation and mutations in normal and benign breast tissue. Int J Cancer 2000; 87: 73-78.
18- Kandel R, Zhu XL, Li SQ, Rohan T: Cyclin D1 protein overexpression and gene amplification in benign breast tissue and breast cancer risk. Eur J Cancer Prev 2001; 10: 43-51.

19- Cote ML, Ruterbusch JJ, Alosh B, Bandyopadhyay S, Sim K, et al: Benign breast disease and the risk of subsequent breast cancer in African American women. Cancer Pre Res 2012; 5(12): 1375-1380.

20- Kabat GC, Jones JG, Olson N, Negassa A, Duggan C, Ginsberg M, et al: A multi center prospective cohort study of benign breast disease and risk of seubsequent breast cancer. Cancer Causes Control 2010; 21(6): 821-828.

21- Schnitt SJ, Jimi A, Kojiro M: The increasing prevalence of benign proliferativebreast lesions in Japanese women. Cancer 1993; 71(8): 2528-253.

22- Hartmann LC, Sellers TA, Frost MA, et al: Benign breast disease and therisk of breast cancer. N Eng J Med 2005; 353(3): 229-237.

23- Chengquan Z, Anwar R, Sue E, et al: Breast fine-needle aspiration samples reported as "Proliferative Breast Lesion”: Clinical utility of the subcategory "Proliferative Breast Lesion with Atypia”. Cancer Cytopatho 2009; 117: 137-147.

24- Okoth C, Galukande M, Gombwe G, et al: Benign proliferative breast diseases among female patients at a sub Saharan Africa tertiary hospital: A cross sectional study. BMC Surgery 2013; 13: 9.

25- Shrestha A, Chalise S, Karki S, et al: Fine needle aspiration cytology in a palpable breast lesion. Journal of Pathology of Nepal 2011; 1: 131-135.

26- Pastides H, Kelsey JL, Holford TR, LiVolsi VA: An epidemiologic study of fibrocystic breast disease with reference to ductal epithelial atypia. Am J Epidemiol 1985; 121: 440-447.

27- Minami Y, Ohuchi N, Taeda y, Fukao A, Hisamichi S: Risk factors for benign breast disease according to histopathological type: Comparisons with risk factors for breast disease. Jpn J Cancer Res 1998; 89: 116-123.

28- Berkowitz GS, Kelsey JL, LiVolsi VA, Holford TR, Merino MJ, Ort S, O’Connor TZ, White C. Risk factors for fibrocystic breast disease and its histopathologic components. J Natl Cancer Inst 1985; 75: 43-50.

29- Bright RA, Morrison AS, Brisson J, Burstein NA, Sadowsky NL, Kopans DB, Meyer JE: 
Histologic and mammographic specificity of risk factors for benign breast disease. Cancer 1989; 64: 653-657.

30- Ingram DM, Nottage E, and RobertsT: The role of diet in the development of breast cancer: A case-control study of patients with breast cancer, benign epithelial hyperplasia and fibrocystic disease of the breast. $\mathrm{Br} \mathrm{J}$ Cancer 1991, 64: 187-191.

31- London SJ, Stein EA, Henderson IC, Stampfer MJ, Wood WC, Remine S, Dmochowski JR, Robert NJ, Willett WC: Carotenoids, retinol, and vitamin e and risk of proliferative benign breast disease and breast cancer. Cancer Causes Control 1992; 3: 503-512.

32- $\mathrm{Wu} \mathrm{C}$, Ray RM, Lin MG, Neilann DLG, Korner NK, Nelson ZC, Lampe JW, Hu YW, Shannon J, Stalsberg H, Li W, Fitzgibbons PL, Porter P, Patterson RE, Satia JA, Thomas DB: A case-control study of risk factors for fibrocystic breast conditions. Shanghai nutrition and breast disease study, china, 1995-2000. Am J Epidemiol 2004; 160: 945-960.

33- Friedenreich CM, Bryant HE, Alexander F, Hugh J, Danyluk J, Page DL: Risk factors for benign proliferative breast disease. Int $J$ Epidemiol 2000; 29: 637-644.

34- Soini I, Aine R, Lauslahti K, Hakama M: Independent risk factors of benign and malignant breast lesions. Am J Epidemiol 1981; 114: 507-514.

35- Parazzini F, La Vecchia C, Franceschi S, Decarli A, Gallus G, Regallo M, Liberati A,
Tognoni G: Risk factors for pathologically confirmed benign breast disease. Am Epidemiol 1991; 120: 115-122.

36- Hsieh CC, Walker AM, Trapido EJ, Crosson AW, MacMahon B: Age at first birth and breast atypia. Int J Cancer 1984; 33: 309-312.

37- Rohan TE, L'Abbe KA Cook MG: Oral contraceptives and risk of benign proliferative epithelial disorders of the breast. Int J Cancer 1992; 50: 891-894.

38- LiVolsi VA, Stadel BV, Kelsey JL, Holford TR, White C: Fibrocystic breast disease in oral-contraceptive users. A histopathological evaluation of epithelial atypia. $N$ Engl J Med 1978; 299: 381-385.

39- Pastides H, Kelsey JL, LiVolsi VA, Holford TR, Fischer DB, Goldenberg IS: Oral contraceptive use and fibrocystic breast disease with special reference to its histopathology. J NatlCancer Inst 1983; 71: 5-9.

40- Berkowitz GS, Kelsey JL, Merino MJ, Holford TR, Hildreth NG, Ort S, O'Connor TZ, White C: Exogenous hormone use and fibrocystic breast disease by histopathologic component. Int J Cancer 1984; 34: 443-449.

41- Rohan TE, Miller AB: Hormone replacement therapy and risk of benign proliferative epithelial disorders of the breast. Eur $J$ Epidemiol 1999; 8: 123-130.

42- Rohan TE, Miller AB: A cohort study of oral contraceptive use and risk of benign breast disease. Int J Cancer 1999; 82: 191-196. 